\title{
Ti-V 合金の微細組織におよばす炭素添加の影響
}

\section{古原 忠 ${ }^{1}$ 安中 聡 2 *1 牧 正志, ${ }^{2} 2$}

\author{
1東北大学金属材料研究所 \\ 2 京都大学工学研究科材料工学専攻
}

J. Japan Inst. Metals, Vol. 72, No. 12 (2008), pp. 942-948 Special Issue on Strategy for Ubiquitous Titanium Alloys (C) 2008 The Japan Institute of Metals

\section{Effect of Carbon Addition on Microstructure of Ti-V Alloys}

Tadashi Furuhara ${ }^{1}$, Satoshi Annaka ${ }^{2, * 1}$ and Tadashi Maki ${ }^{2, * 2}$

${ }^{1}$ Institute for Materials Research, Tohoku University, Sendai 980-8577

${ }^{2}$ Department of Materials Science and Technology, Kyoto University, Kyoto 606-8501

Effects of carbon addition on microstructure of $\mathrm{Ti}-\mathrm{V}$ alloys formed at high temperatures were investigated.

By adding carbon to pure Ti and Ti-V binary alloys, precipitation of TiC occurs. With increase of vanadium content, $\beta /(\beta+$ $\mathrm{TiC})$ phase boundary shifts to the lower carbon side slightly. On the other hand $(\alpha+\beta) /(\alpha+\beta+\mathrm{TiC})$ boundaries shifts largely with decreases in $\alpha$ fraction and peritectoid reaction temperature by addition of vanadium.

Addition of carbon to a $\mathrm{Ti}-15 \mathrm{~V}-3 \mathrm{Cr}-3 \mathrm{Sn}-3 \mathrm{Al}$ alloy results in extensive suppression of recovery during hot deformation of $\beta$ phase by carbon in solution. Also age hardening kinetics of $\mathrm{Ti}-15 \mathrm{~V}-3 \mathrm{Cr}-3 \mathrm{Sn}-3 \mathrm{Al}$ after $\beta$ solutionizing was accelerated by carbon addition.

(Received July 29, 2008; Accepted September 19, 2008)

Keywords: titanium alloy, interstitial element, phase equilibrium, precipitation, hot deformation

\section{1. 緒言}

従来，チタン合金の開発においては，侵入型元素は延勒性 の低下をもたらす不純物として嫌われていた。しかしなが ら, 近年低コスト化などの観点から, 酸素 $(\mathrm{O}) \cdot$ 窒素 $(\mathrm{N})$ に よる固溶強化を利用した $\alpha$ 型合金 $(\mathrm{Ti}-\mathrm{Fe}-\mathrm{O}-\mathrm{N} \text { 合金) })^{1)}$ や高 温での加工性を落とさず, 室温強度を高める炭素 $(\mathrm{C})$ を添加 して $\mathrm{Al}$ 添加量を下げた $\alpha+\beta$ 型合金 $(\mathrm{Ti}-\mathrm{Al}-\mathrm{Cr}-\mathrm{C})^{2)}$ など, 侵入型元素の積極的利用が実用合金で行われている. しかし， $\beta$ 型合金での侵入型元素の利用に関する研究は少ない.

$\mathrm{V}$ は Mo とともに $\beta$ 安定化元素として実用的に最も使わ れている添加元素である. $\mathrm{Ti}-\mathrm{V}$ 二元合金の状態図は， $\beta$ 開 放型であった ${ }^{3)}$ が，一時偏析反応 $\left(\beta \rightarrow \beta^{\prime}+\alpha\right)$ が存在する状態 図 ${ }^{4)}$ が提唱され，近年再度 $\beta$ 開放型の状態図 ${ }^{5,6}$ に修正されて いる．著者らは以前 $\mathrm{Ti}-\mathrm{Mo}$ 合金についても同様に $\beta$ 開放型 の状態図がより妥当であるとの提唱を行っている7).

$\mathrm{Ti}-\mathrm{V}$ 合金に打ける炭素 $(\mathrm{C})$ の活用例は， Ti-15V-3Cr3Sn-3Al 合金の時効硬化の促進 ${ }^{8,9)}$, 炭化物分散による $\mathrm{Ti}-$ 6Al-4V 合金の耐摩耗性の改善 ${ }^{10)}$ があるが，未だ少ない。そ の理由として相平衡・相変態におよぼす C 添加の影響が明

*1 京都大学大学院生, 現在 : トヨタ自動車秼)(Graduate Student, Kyoto University, Present address: Toyota Motors Corporation)

*2 京都大学名誉教授, 現在 : 新日本製鐵侏)(Professor Emeritus, Present address: Nippon Steel Corporation)
らかにされていないことがある. Ti-C 二元系状態図の研究 は過去に詳細になされている11,12)が，その他については Ti$\mathrm{V}-\mathrm{C}$ 三元系で一部等温断面の研究 ${ }^{13,14)}$ があるだけであり, 詳細は不明である。

以上のことより，本研究では実用的に最も多く用いられて いる $\beta$ 安定化元素である V に注目し, $\mathrm{Ti}-\mathrm{V}-\mathrm{C}$ 三元系合金 に拈いて $\beta$ 域から $\alpha+\beta$ 域にかけての種々の温度において得 られる相平衡組織の同定を行い, $\mathrm{Ti}-\mathrm{V}$ 合金での相平衡·相 変態への炭素添加の影響について明らかにする. また, 実用 $\beta$ 型合金である $\mathrm{Ti}-15 \mathrm{~V}-3 \mathrm{Cr}-3 \mathrm{Sn}-3 \mathrm{Al}$ 合金への炭素添加の 影響についても検討を行ったので報告する.

Table 1 Chemical compositions of $\mathrm{Ti}-\mathrm{V}-\mathrm{C}$ alloys used in the present study (mass\%).

\begin{tabular}{cccccc}
\hline & $\mathrm{V}$ & $\mathrm{C}$ & $\mathrm{O}$ & $\mathrm{N}$ & $\mathrm{Ti}$ \\
\hline $\mathrm{Ti}-0.1 \mathrm{C}$ & $<0.1$ & 0.12 & 0.068 & 0.004 & bal. \\
\hline $0.2 \mathrm{C}$ & $<0.1$ & 0.24 & 0.11 & 0.006 & bal. \\
\hline $0.4 \mathrm{C}$ & 0.1 & 0.38 & 0.085 & 0.010 & bal. \\
\hline $\mathrm{Ti}-3 \mathrm{~V}-0.1 \mathrm{C}$ & 3.05 & 0.12 & 0.083 & 0.005 & bal. \\
\hline $0.2 \mathrm{C}$ & 3.07 & 0.22 & 0.090 & 0.006 & bal. \\
\hline $0.3 \mathrm{C}$ & 3.06 & 0.35 & 0.11 & 0.007 & bal. \\
\hline $0.4 \mathrm{C}$ & 3.07 & 0.39 & 0.076 & 0.008 & bal. \\
\hline $\mathrm{Ti}-8 \mathrm{~V}-0.05 \mathrm{C}$ & 8.10 & 0.080 & 0.080 & 0.005 & bal. \\
\hline $0.1 \mathrm{C}$ & 8.08 & 0.12 & 0.086 & 0.007 & bal. \\
\hline $0.2 \mathrm{C}$ & 7.94 & 0.22 & 0.082 & 0.006 & bal. \\
\hline
\end{tabular}




\section{2. 実 験 方 法}

Ti-V-C 三元系の相平衡の研究の供試材として, Table 1
に示す $\mathrm{Ti}-\mathrm{C}$ 二元合金打よび $\mathrm{Ti}-\mathrm{V}-\mathrm{C}$ 三元合金のボタン状試 料を Arガス雾团気中でのアーク溶解により作製した．C 添 加は $\mathrm{TiC}$ 粉末の混合抢よび溶解によって行った。その後全 てのボタン状試料について $1033 \mathrm{~K}$ での 50〜 75\%の温間圧
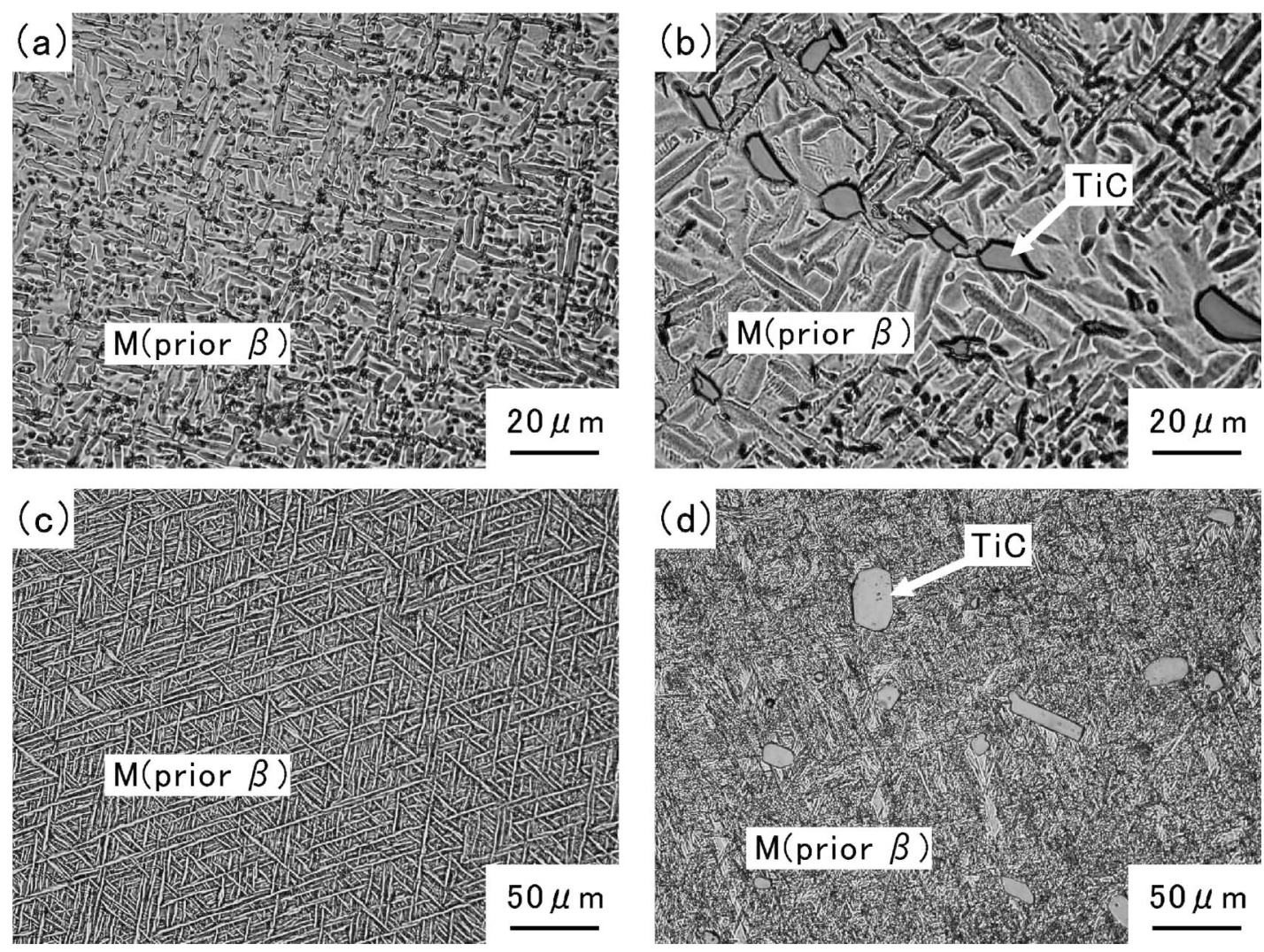

Fig. 1 Optical microstructures observed in Ti-C alloys, (a) Ti-0.2C, $1573 \mathrm{~K}$, (b) Ti-0.4C, $1573 \mathrm{~K}$, (c) Ti-0.1C, $1473 \mathrm{~K}$, (d) Ti$0.2 \mathrm{C}, 1473 \mathrm{~K}$.
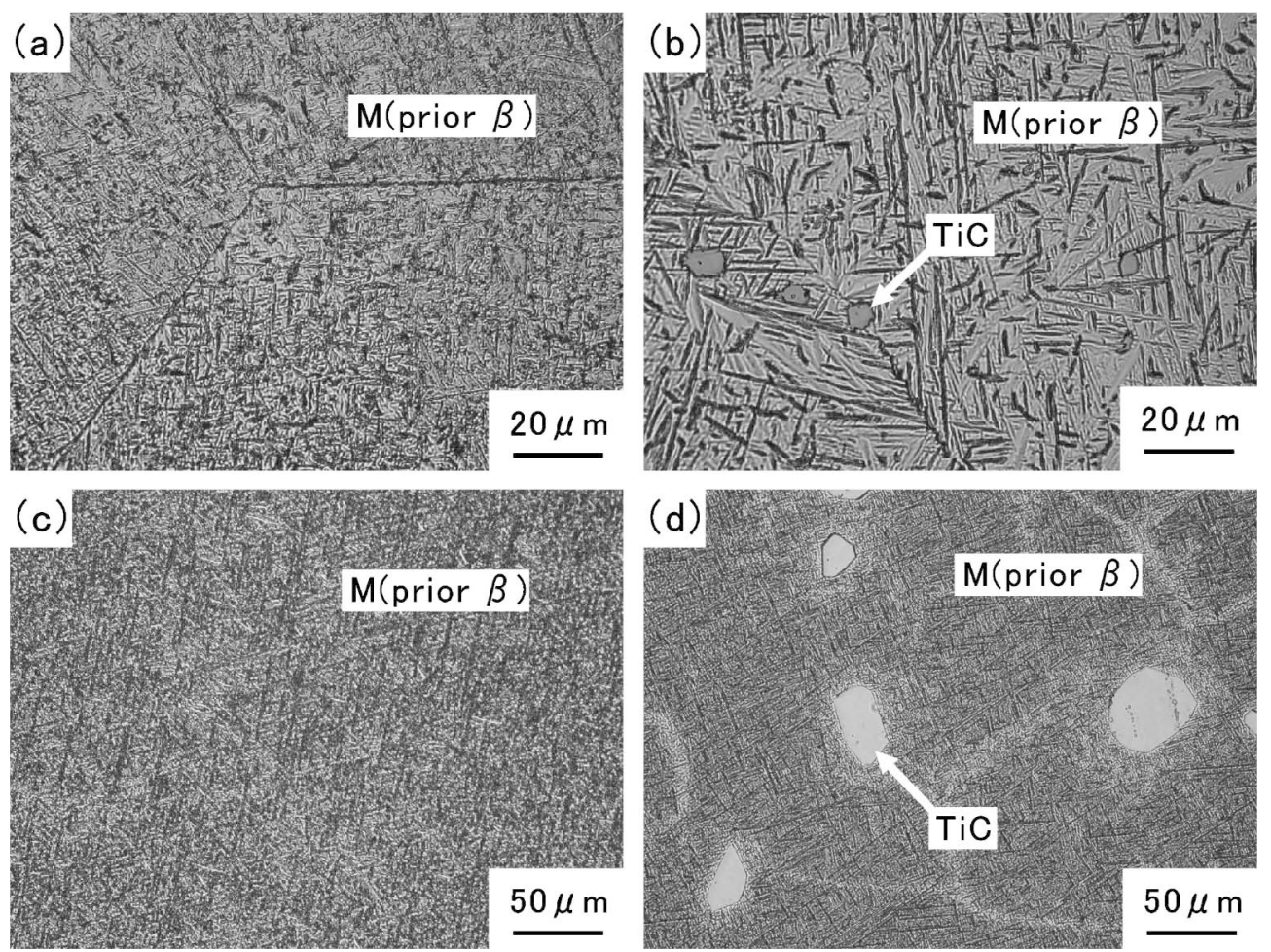

Fig. 2 Optical microstructures observed in the Ti-3V-C alloys, (a) Ti-3V-0.2C, $1573 \mathrm{~K}$, (b) Ti-3V-0.3C, $1573 \mathrm{~K}$, (c) Ti-3V$0.1 \mathrm{C}, 1473 \mathrm{~K}$, (d) Ti-3V-0.2C, $1473 \mathrm{~K}$. 
延を施し厚さ $3 \mathrm{~mm}$ の板材に仕上げた．電子線マイクロアナ ライザー(EPMA)による分析の結果, 溶解まま試料の V の 凝固偏析はほとんど認められなかったが, 微量偏析による組 織への影響をなくすために, Ti-3V- $(0.1,0.2 \mathrm{C})$ と Ti-8V$(0.05,0.1) \mathrm{C}$ 合金について石英管中に $\mathrm{Ar}$ ガス封入し, $\beta$ 単 相域である $1473 \mathrm{~K}, 86.4 \mathrm{ks}$ の均一化処理を行った。一方, より高 Cの合金については析出物が固溶しないことから, 溶解後温間圧延材をそのままその後の熱処理に用いた。

各試料は石英管中に Ar ガス封入し，973～1473 K の種々 の温度で $86.4 \mathrm{ks}$ 等温保持した後, 水中に焼入れ, 直ちに石 英管を割ることによって急冷し，組織観察を行った。1473 $\mathrm{K}$ 以上の温度では石英管が軟化し，封入ができないため, 酸化等の影響を避けるために $\mathrm{Ti}$ 䈃で包み, 真空中で $3.6 \mathrm{ks}$ 等温保持した後, 水中に焼入れ, 組織観察を行った.

また， $\beta$ 相中の固溶 C および炭化物が, 高温での変形組織 や時効硬化挙動におよぼす影響について調べる目的で, 実用 合金 $\mathrm{Ti}-15 \mathrm{~V}-3 \mathrm{Cr}-3 \mathrm{Sn}-3 \mathrm{Al}(\operatorname{mass} \%$ ) 合金に 0.05, 0.1, 0.5 mass\%の炭素を添加した合金を作製した。これらについて
は, 溶解後ボタン材から直接 $8 \mathrm{~mm}^{\phi} \times 12 \mathrm{~mm}^{\mathrm{h}}$ の円柱状試験 片を切り出し直接 $1273 \mathrm{~K}$ および $1073 \mathrm{~K}$ に加熱した後温間 圧縮変形 (初期丕速度 : $4.2 \times 10^{-3} \mathrm{~s}^{-1}$ )を行った。 また 1423 $\mathrm{K}$ での $\beta$ 溶体化水冷後 $773 \mathrm{~K}$ で種々の時間等温時効を行っ た. 一部には溶体化水冷材に冷間圧延を施した後同じ時効処 理を施した。

組織観察は光学顕微鏡, SEM-EBSD および TEM を用い て行い, 時効硬化挙動をマイクロビッカース硬度測定 (load: $9.8 \mathrm{~N})$ により調べた.

\section{3. 実験結果および考察}

\section{$3.1 \beta$ 相中の $\mathrm{TiC}$ 析出}

Fig. 1 に Ti-C 二元合金の $1573 \mathrm{~K}$ で $3.6 \mathrm{ks}$ および $1473 \mathrm{~K}$ で $86.4 \mathrm{ks}$ の等温保持によって形成された組織の光学顕微鏡 写真を示す。この温度では $\alpha$ 相の析出は見られない.ほぼ 全面が保持温度では $\beta$ 単相で, その後の急冷によって形成 されたマルテンサイト的な板状もしくは針状の変態組織を呈
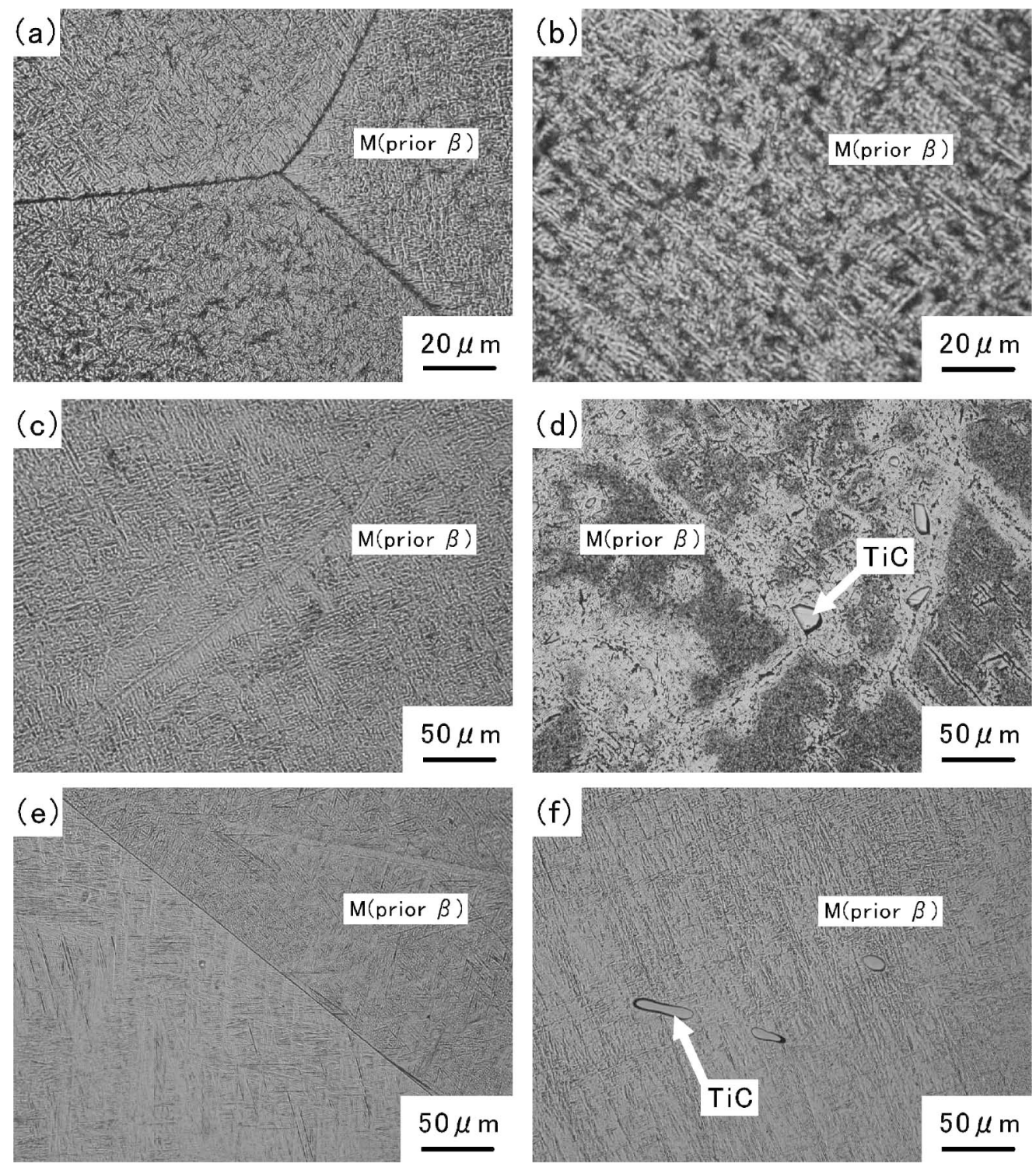

(f)

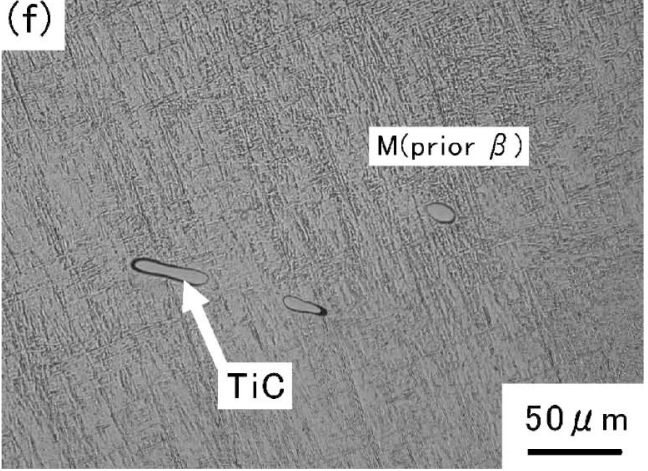

Fig. 3 Optical microstructures observed in the Ti-8V-C alloys, (a) Ti-8V-0.1C, $1573 \mathrm{~K}$, (b) $\mathrm{Ti}-8 \mathrm{~V}-0.2 \mathrm{C}, 1573 \mathrm{~K}$, (c) Ti-8V$0.1 \mathrm{C}, 1473 \mathrm{~K}$, (d) Ti-8V-0.2C, $1473 \mathrm{~K}$, (e) Ti-8V-0.05C, $1373 \mathrm{~K}$, (f) Ti-8V-0.1C, $1373 \mathrm{~K}$. 
する. $1573 \mathrm{~K}$ では (a)の Ti-0.2C 合金は完全に $\beta$ 単相であ るが (b)の Ti-0.4C 合金では $\mathrm{TiC}$ が一部存在する. $1473 \mathrm{~K}$ では $\mathrm{TiC}$ は (c)の Ti-0.1C 合金では観察されないが，（d)の $0.2 \mathrm{C}$ 合金では存在する。これらの $\mathrm{TiC}$ は $\beta$ 溶体化温度でも 一部未固溶であったと思われる.

Fig. 2 は Ti-3V-C 合金の 1573 K および 1473 K 保持によ って形成された組織の光学顕微鏡写真である.（a）の Ti$3 \mathrm{~V}-0.2 \mathrm{C}$ 合金では高温での $\beta$ 単相組織が，室温への焼入れ 時にマルテンサイト変態した組織を呈する. 一方 C 添加量 が 0.3\%になると (Fig. 2(b))， $\beta$ 中に炭化物 (TiC) が分散し た組織が得られる。 $1473 \mathrm{~K}$ 保持の場合，（c）の Ti-3V-0.1C 合金では $\beta$ 単相であるのに対して，(d)の $0.2 \% \mathrm{C}$ 添加材で は $\beta$ 中に炭化物 ( $\mathrm{TiC}$ ) が未固溶で残存する.すなわち, $\mathrm{Ti}-$ $3 \mathrm{~V}-\mathrm{C}$ 合金に拈いても温度の低下にともない， $\beta$ 相中の $\mathrm{C}$ 固 溶限は低下することがわかる。

Fig. 3 は，Ti-8V-(0.05-0.2) C 合金の $1573 \mathrm{~K}, 1473 \mathrm{~K}$ お よび $1373 \mathrm{~K}$ 保持によって形成された組織の光学顕微鏡写真 である。（a）抢よび(b)を見ると， $1573 \mathrm{~K}$ では 0.2 mass\%ま
での C は十分 $\beta$ 相中に固溶することがわかる，一方， 1473 $\mathrm{K}$ になると $0.2 \mathrm{C}$ 合金において炭化物が生成し (Fig. 3(d)), $1373 \mathrm{~K}$ では C 固溶限は 0.1 mass\%よりも少ない (Fig. 3 (e) および(f)参照).

Fig. 4 は，Ti-C および Ti-3V-C 合金を $1173 \mathrm{~K}$ で保持し た場合の光学顕微鏡組織である。(a)，(c) および (e)を比較 すると炭素量の増大に伴って $\alpha$ 相の分率が増大するのがわ かる。一方同じ炭素量で比較すると V 添加により $\alpha$ 相の分 率は減少する，例えば，（e）と（f)を比較すると， Ti-0.4C 合 金では $\alpha$ 相が大部分を占める $(\alpha+\beta)$ 二相組織であるが， 3 $\operatorname{mass} \% \mathrm{~V}$ の添加により $\mathrm{C}$ 量が $0.3 \%$ でも $\alpha$ 相は消失し, $\beta+$ $\mathrm{TiC}$ 二相組織になっている.

Fig. 5 は，Ti-3V-C 合金を $1073 \mathrm{~K}$ で保持した組織であ る. (a)の $0.1 \mathrm{C}$ 合金では， $\beta$ 溶体化焼入れによりマルテンサ イトに変態した後の等温保持により $(\alpha+\beta)$ 二相組織を呈す る. (b)の $0.2 \mathrm{C}$ 合金では $\beta$ 相中に残留する $\mathrm{TiC}$ 粒子の周囲 に $\alpha$ 相の生成が見られ包析反応が起こっている。また炭素 量がさらに増加すると $\alpha$ 相の量が大きくなる(Fig. 5(c)).
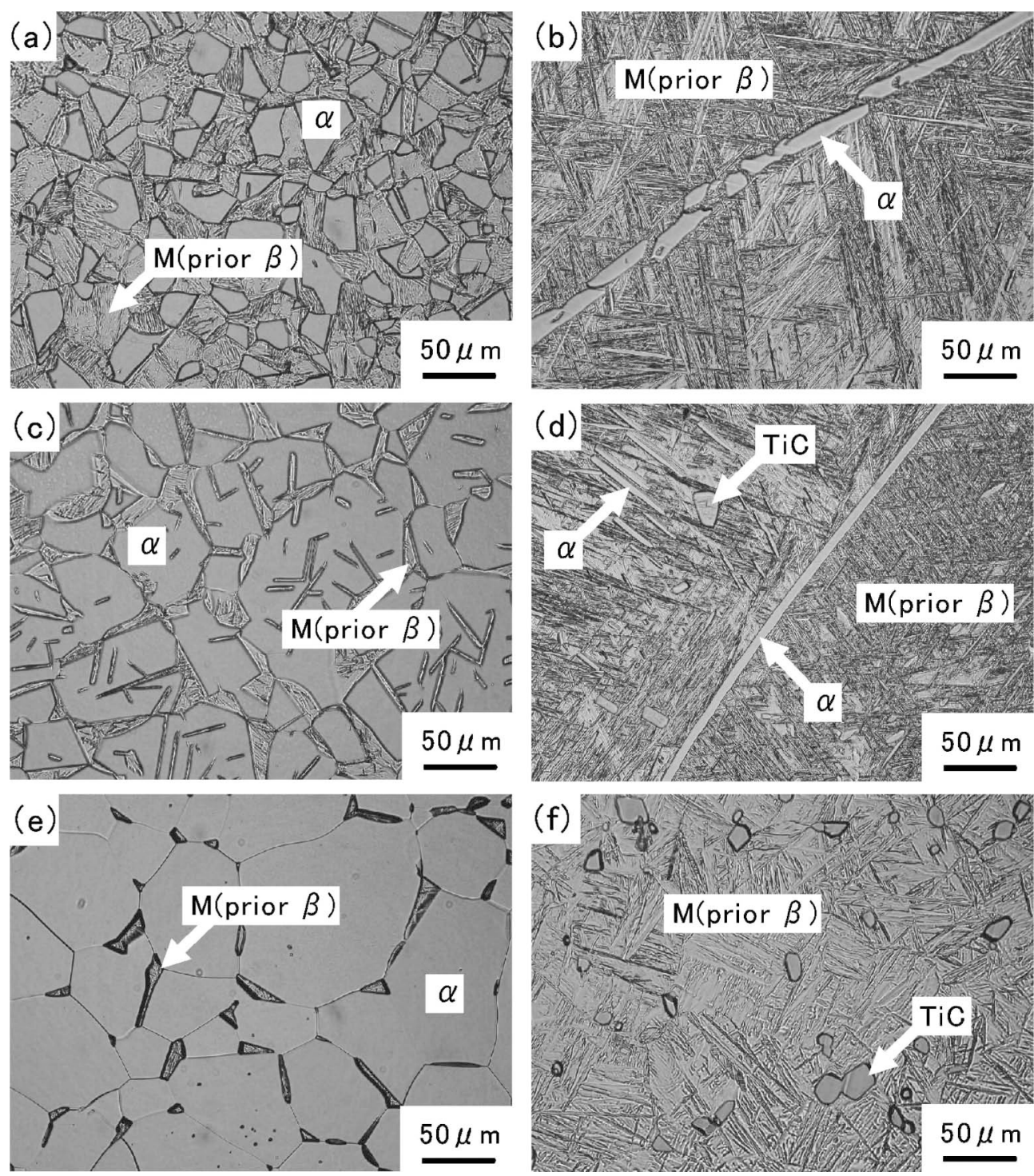

Fig. 4 Optical microstructures observed in the $\mathrm{Ti}-\mathrm{V}-\mathrm{C}$ alloys held at $1173 \mathrm{~K}$ : (a) $\mathrm{Ti}-0.1 \mathrm{C}$, (b) $\mathrm{Ti}-3 \mathrm{~V}-0.1 \mathrm{C},(\mathrm{c}) \mathrm{Ti}-0.2 \mathrm{C},(\mathrm{d}) \mathrm{Ti}-$ $3 \mathrm{~V}-0.2 \mathrm{C}$, (e) $\mathrm{Ti}-0.4 \mathrm{C}$, (f) $\mathrm{Ti}-3 \mathrm{~V}-0.3 \mathrm{C}$. 

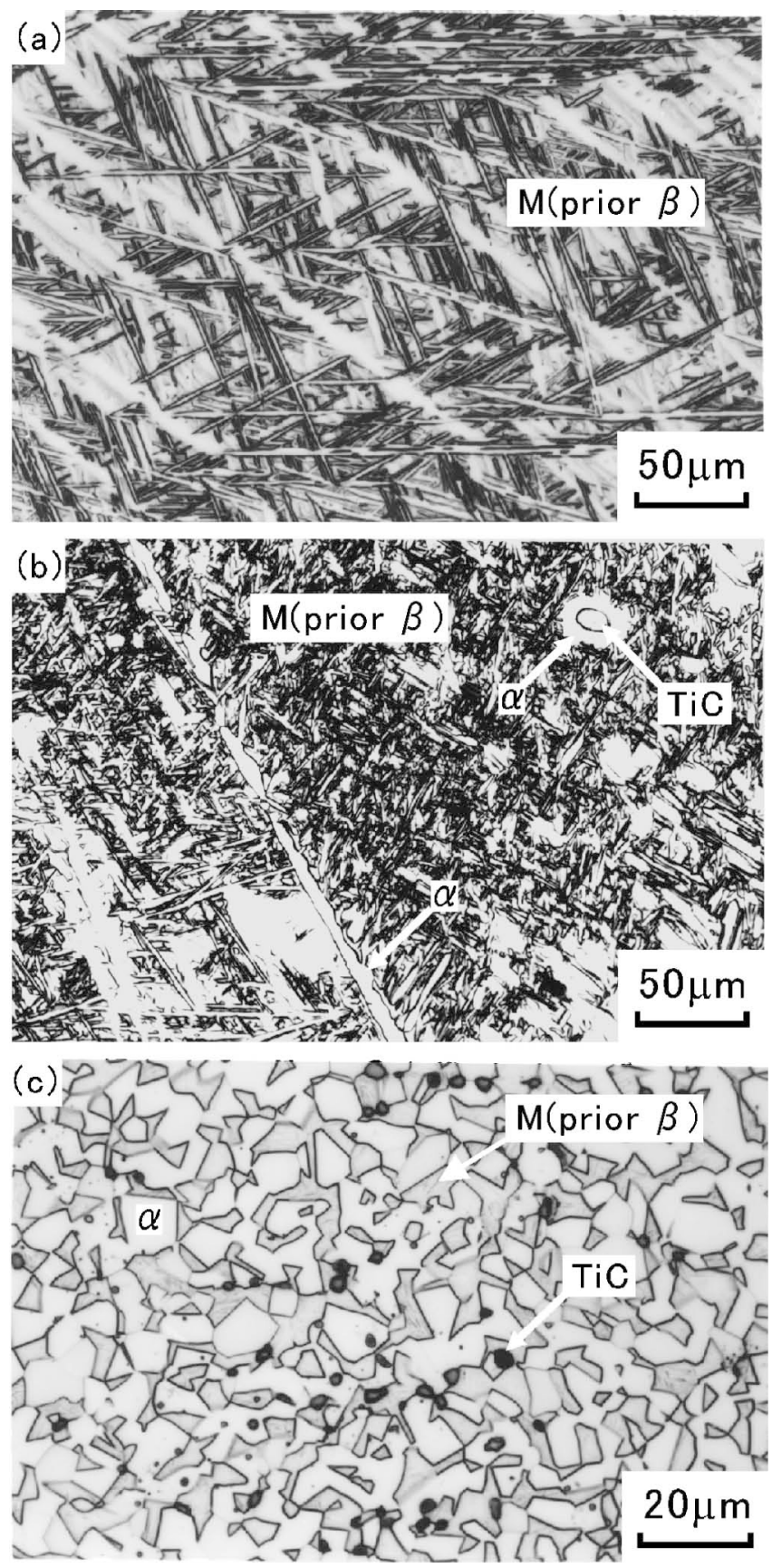

Fig. 5 Optical microstructures observed in the Ti-3V-C alloys held at $1073 \mathrm{~K}$ : (a) $0.1 \mathrm{C}$, (b) $0.2 \mathrm{C}$, (c) $0.3 \mathrm{C}$.

Fig. 6 に, 本研究における組織観察結果を Thermo-Calc による計算状態図 (垂直断面図) 扮よび過去の実験的研究11,12) で求められた相境界と共に示す。（a）の Ti-C二元合金の観 察結果は Thermo-Calcによる計算状態図とはほぼ一致す る。ただし，包析温度直上に抢ける $\beta$ 中の $\mathrm{C}$ 固溶限は，以 前の報告よりも若干低 C 側にあることが分かる，一方，(b) および(c)の Ti-V-C 三元系の結果を二元系の場合と比較す ると, $\mathrm{V}$ を添加することにより $\beta$ 相中の $\mathrm{C}$ 固溶限はわずか に低下し， $\alpha$ 相の生成する温度域も低下しているのがわか る.この観察結果を Thermo-Calc を用いた計算結果と比べ ると, 包析温度以上での $\beta /(\beta+\mathrm{TiC})$ 相境界は両者でほぼ一 致している. しかしながら, 包析温度以下では $(\alpha+\beta) /(\alpha+$ $\beta+\mathrm{TiC})$ 相境界が計算よりも若干高 $\mathrm{C}$ 側にずれている. 以上
の観察結果より，Ti-V 合金においても C 添加により炭化物 の固溶・析出を組織制御に利用できると考えられる.

\section{$3.2 \mathrm{Ti}-15 \mathrm{~V}-3 \mathrm{Cr}-3 \mathrm{Sn}-3 \mathrm{Al}$ 合金の組織におよぼす炭素添加 の影響}

Fig. 7 は，Ti-15V-3Cr-3Sn-3Al 合金の C-free 材および

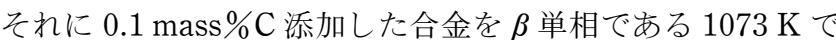
$50 \%$ 圧縮変形した組織である。ただ， $0.1 \% \mathrm{C}$ 添加材では 一部 TiC 粒子が分散している。両合金とも元の $\beta$ 粒が圧縮 面に沿って扁平になっているが，(a)，(b)のC-free 材で は，以前 ${ }^{15)}$ に報告した通り，粒内に小角粒界が多く形成さ れると同時に，元の粒界付近にセレーションや動的再結晶に より生成したと考えられる大角粒界で囲まれた等軸粒 (図中 の円内参照) が観察される。一方， $0.1 \% \mathrm{C}$ 添加材では，粒内 に方位差はほとんどなく，粒界にも顕著なセレーションは見 られない。この原因としては，固溶炭素によるドラッグ効果 もしくは分散する $\mathrm{TiC}$ 粒子によるピン止め効果により粒界 移動が抑制されていることが考えられる. Fig. 8 は C-free 材と $0.1 \% \mathrm{C}$ 添加材の加工材の TEM 写真である. (a)の Cfree 材では粒内の動的回復が顕著で亜粒界以外には転位が あまり見られないのに対して，（b）の $0.1 \% \mathrm{C}$ 添加材では高 密度な転位が均一に分布している，これより，固溶炭素の存 在により $\beta$ 相中の変形組織の回復が大きく抑制されること が明らかである。

Fig. 9 は 0.5 mass\%C を添加した合金を $1073 \mathrm{~K}$ で 50\%圧 縮した試料の光学顕微鏡写真および対応する $\beta$ 方位マップ である. 初期組織では等軸 $\beta$ 粒中に多くの TiC 粒子が列状 に分散していたが，圧縮変形によって TiC 周囲に比較的方 位差の大きな領域が生まれているのがわかる。この方位差の 形成は硬質粒子である $\mathrm{TiC}$ の周囲に変形時に導入された転 位が集積するために起こると考えられる.

Fig. 10 は， $0.1 \% \mathrm{C}$ 添加による Ti-15V-3Cr-3Sn-3Al 合 金の $773 \mathrm{~K}$ での時効硬化曲線の変化である．溶体化後時効 $(\mathrm{S} . \mathrm{T} .+\mathrm{A})$ では $\mathrm{Wu} 5^{8,9)}$ の報告と同様，C 添加により時効硬 化速度が大きくなる。しかしながら，時効による硬度の上昇 分は $\mathrm{C}$ 添加の有無に関わらずほとんど同じである。C 添加 材ではほぼ溶体化ままでの C の固溶強化量の分だけ硬度上 昇があると言える。このことは，時効硬化量も C 添加によ り増加するとした Wuらの結果とは異なっている。一方, $0.1 \mathrm{C}$ 材に溶体化後 $25 \%$ 冷間圧延を施すと，その後の時効に よる硬化速度はさらに大きくなり，C-free 材の強冷延-時効 材よりも高い硬度を示す。これは時効処理中の回復による転 位密度の減少が C 添加によって抑制されるため， $\alpha$ 相析出が より微細に起こることが考えられる。しかしながら， $\alpha$ 相中 への C の濃縮等も含めてより詳細な検討が必要である。 た， C 添加により $\beta$ 溶体化後の冷間加工性は著しく損なわれ ることがわかった．Fig. 8(b)の 1073 K，50\%圧縮材を 773 $\mathrm{K}$ で時効すると，25\%冷延材とほぼ同様の硬度が得られ る. 冷延材ではすべり変形が局在化するのに対して高温変形 時には均一な転位分散が得られたことから，より良好な機械 的特性が期待できるが，今後実際の強度一延性バランスの改 善などでは $\mathrm{C}$ 添加量や熱処理条件の最適化を行う必要があ 
(a) $\mathrm{Ti}-\mathrm{C}$

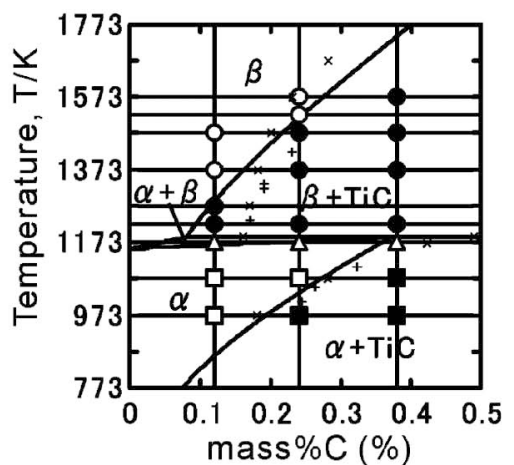

(b) $\mathrm{Ti}-3 \mathrm{~V}-\mathrm{C}$

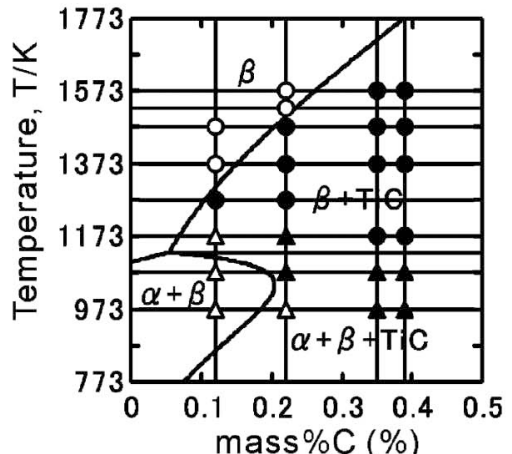

(c) $\mathrm{Ti}-8 \mathrm{~V}-\mathrm{C}$

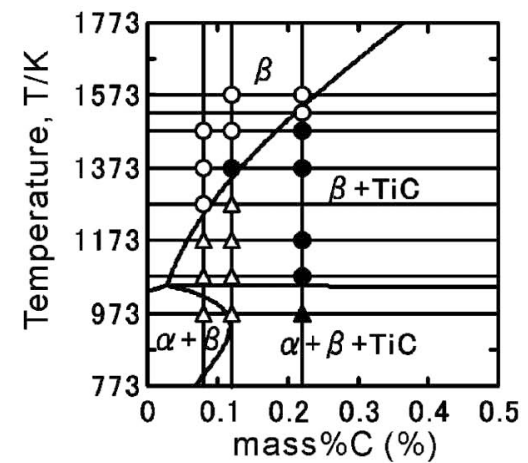

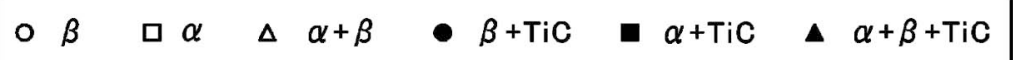
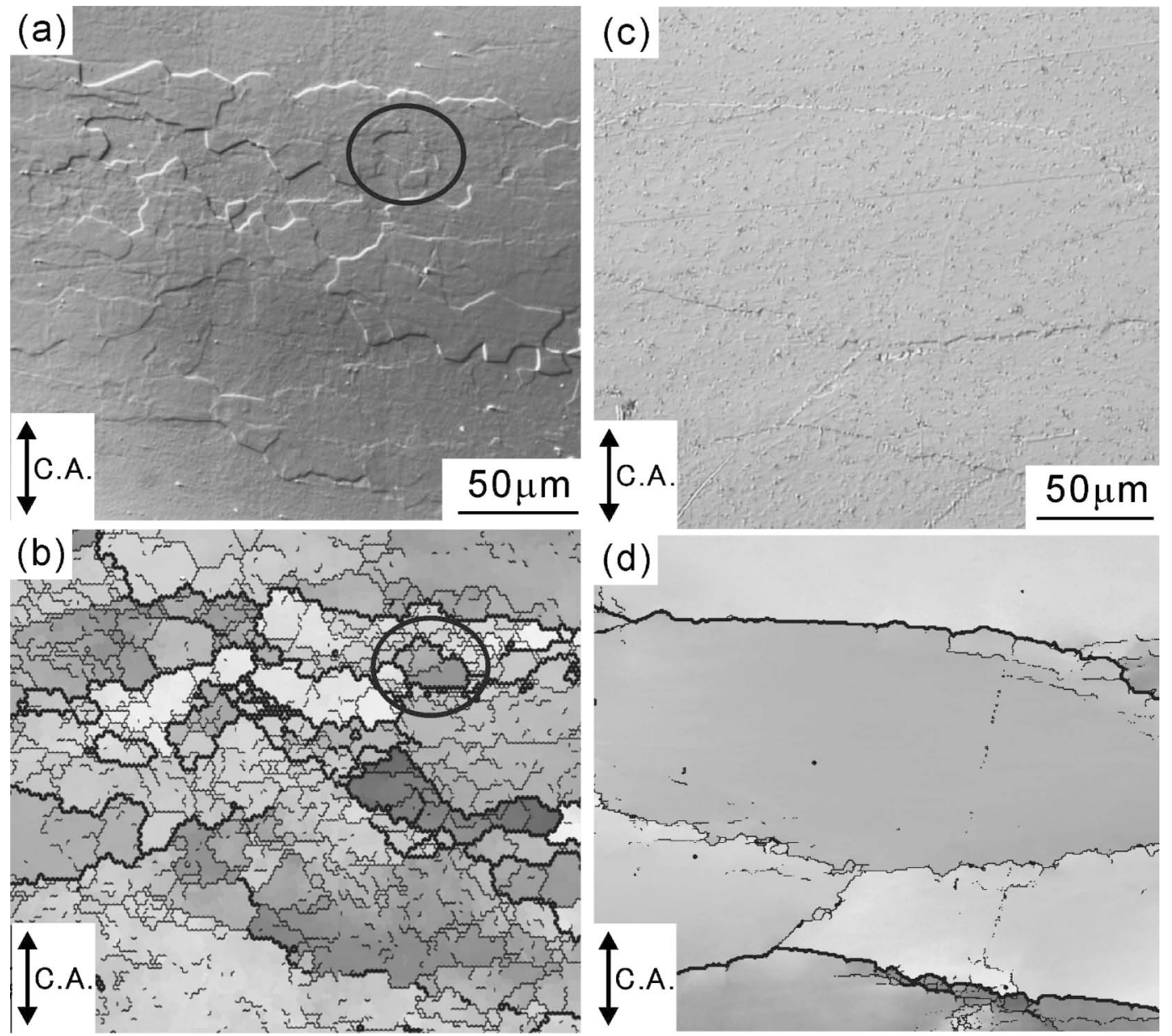

Fig. 7 Optical microstructures and corresponding orientation maps after $50 \%$ compression at $1273 \mathrm{~K}$ with an initial strain rate of $4.2 \times 10^{-3} \mathrm{~s}^{-1}$; (a), (b) Ti-15-3 (C-free), and (c), (d) Ti-15-3-0.1C. Thin and thick solid lines represent low-angle $\beta$ boundaries, of which misorientations are less than 15 degrees, and high-angle $\beta$ boundaries, respectively.

\section{ると考えられる．}

\section{4. 結言}

以上，本研究では，Ti 合金に打り $\mathrm{C}$ 添加による組織へ の影響を明らかにするため, $\mathrm{Ti}-\mathrm{C}$ 二元合金, $\mathrm{Ti}-\mathrm{V}-\mathrm{C}$ 三元 合金について, 包析組成, 包析温度周辺の平衡組織について
調べた. 以下に得られた結果を示す。

(1) $\mathrm{Ti}-\mathrm{C}$ 二元系における $\beta$ 相に対する $\mathrm{C}$ 固溶限は温度低 下に伴って低 $\mathrm{C}$ 側に移行する. 本研究の結果は過去の報告 ともほぼ一致しているが, 包析温度直上の $1223 \mathrm{~K}, 1273 \mathrm{~K}$ での C 固溶限は本研究の結果のほうがより低 C 側にある.

(2) $\mathrm{V}$ 添加により， $\beta$ 相に対する $\mathrm{C}$ 固溶限は低 $\mathrm{C}$ 側に, 包析温度は低温側にそれぞれ移行する. また $\mathrm{Ti}-\mathrm{V}-\mathrm{C}$ 三元系 

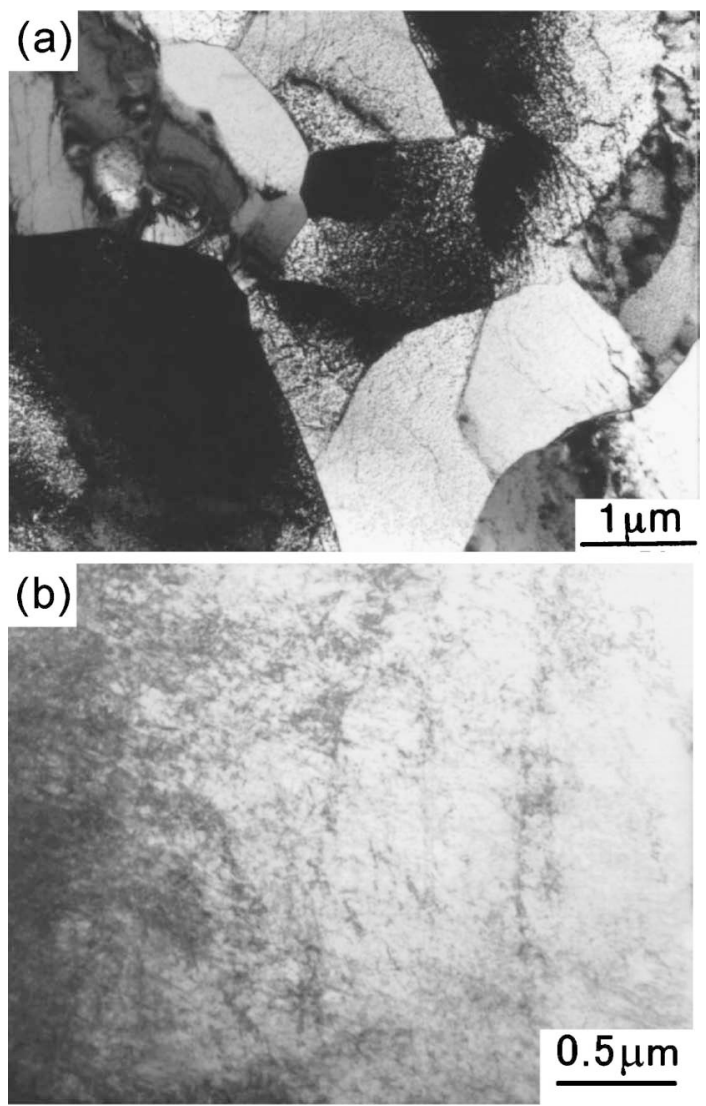

Fig. 8 TEM microstructure of specimens deformed by $50 \%$ compression at $1273 \mathrm{~K}$ with an initial strain rate of $4.2 \times 10^{-3}$ $\mathrm{s}^{-1}$; (a) $\mathrm{Ti}-15 \mathrm{~V}-3 \mathrm{Cr}-3 \mathrm{Sn}-3 \mathrm{Al}$, (b) $\mathrm{Ti}-15 \mathrm{~V}-3 \mathrm{Cr}-3 \mathrm{Sn}-3 \mathrm{Al}-$ $0.1 \mathrm{C}$.
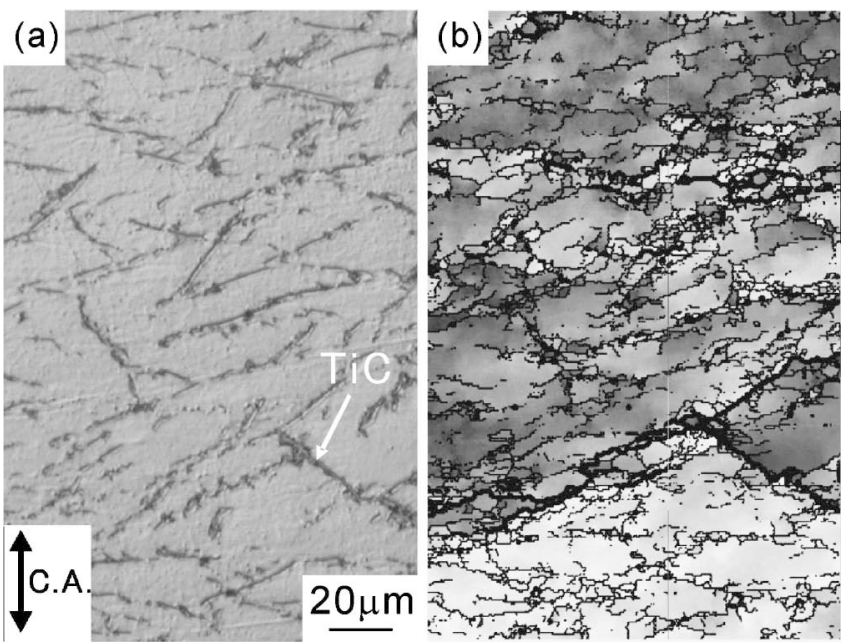

Fig. 9 (a) Optical microstructures and (b) corresponding orientation maps of $\mathrm{Ti}-15 \mathrm{~V}-3 \mathrm{Cr}-3 \mathrm{Sn}-3 \mathrm{Al}-0.5 \mathrm{C}$ after $50 \%$ compression at $1073 \mathrm{~K}$; (a), (b) Ti-15V-3Cr-3Sn-3Al (Cfree), and (c), (d) Ti-15V-3Cr-3Sn-3Al-0.5C. Thin and thick solid lines represent low-angle $\beta$ boundaries and high-angle $\beta$ boundaries, respectively.
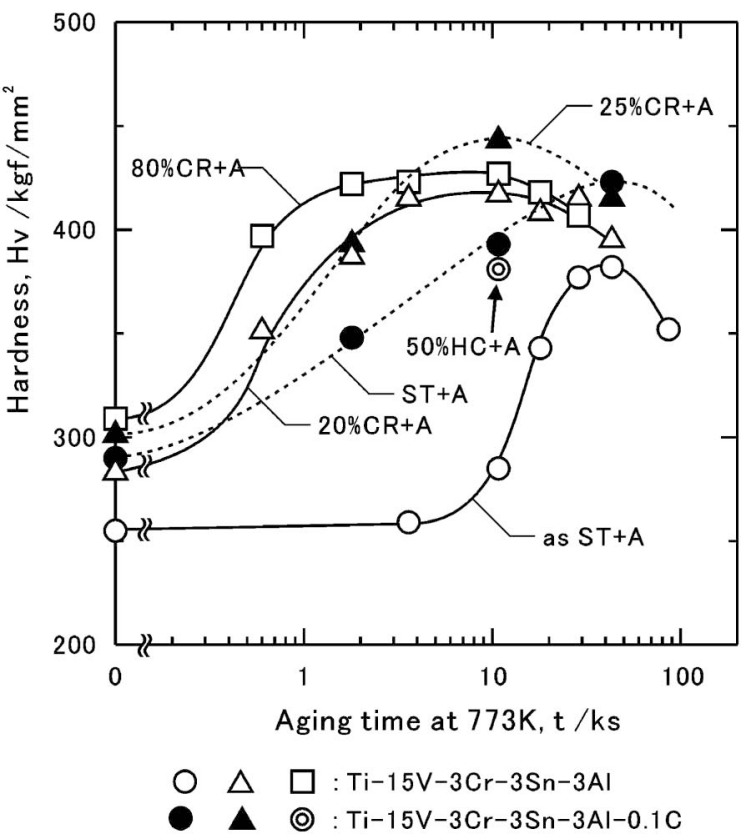

Fig. 10 Hardness change of $\mathrm{Ti}-15 \mathrm{~V}-3 \mathrm{Cr}-3 \mathrm{Sn}-3 \mathrm{Al}-\mathrm{C}$ alloys by aging at $773 \mathrm{~K}$. S.T.: $\beta$ solution treatment, C.R.: cold rolled, H.C.: hot compressed, A: aged.

における $(\alpha+\beta) /(\alpha+\beta+\mathrm{TiC})$ 相境界は温度低下に伴って高 $\mathrm{C}$ 側に移行する.

（3） $\mathrm{Ti}-15 \mathrm{~V}-3 \mathrm{Cr}-3 \mathrm{Sn}-3 \mathrm{Al}$ 合金への C 添加は， $\beta$ 相の熱 間変形時の動的回復を抑制すると共に，および時効時の $\alpha$ 析出による時効硬化を促進する.

文献

1) H. Fujii, S. Soeda, M. Hanaki and H. Okano: Titanium '95 Science and Technology, ed. by P. A. Blenkinsop, W. J. Evans and H. M. Flower, (TIM, UK, 1996) pp. 2309-2316.

2) S. Kojima and H. Oyama: Ti-2003 Science and Technology, ed. by G. Lutjering and J. Albrecht, (Wiley-VCH, Germany, 2003) pp. 3089-3095.

3) J. L. Murray: Bull. Alloy Phase Diagrams 2(1981) 48-55.

4) J. L. Murray: Phase Diagrams of Binary Titanium Alloys, (ASM International, 1990) pp. 47-51.

5) Wei Fuming and H. M. Flower: Mater. Sci. Tech. 5(1989) $1172-1177$

6) H. Okamoto: J. Phase Equil. 16(1995) 202-203.

7) T. Furuhara, T. Makino, Y. Idei, H. Ishigaki, A. Takada and T. Maki: Mater. Trans. JIM 39(1998) 31-39.

8) X. Wu, M. H. Lorreto and D. Hu: Ti-2003 Science and Technology, ed. by G. Lutjering and J. Albrecht, (Wiley-VCH, Weinheim, 2004) pp. 1067-1074.

9) X. Wu, J. del Prado, Q. Li, A. Huang, D. Hu and M. H. Loretto: Acta Mater. 54 (2006) 5433-5448.

10) W. Takahashi, M. Okada, Y. Shida and M. Nakanishi: Tetsuto-Hagane $\mathbf{7 7}$ (1991) 1336-1343.

11) I. Cadoff and J. P. Nielsen: Trans. AIME 197 (1953) 248-252.

12) F. C. Wagner, E. J. Bucur and M. A. Steinberg: Trans. ASM 48 (1956) 742-761.

13) M. Enomoto: J. Phase Equil. 17 (1996) 237-247.

14) T. F. Fedrov, L. V. Gorshkova and E. I. Gladyshevsky: Izvest. Akad. Nauk SSSR 4(1966) 128.

15) T. Furuhara, Y. Toji, H. Abe and T. Maki: Mater. Sci. Forum 426-4(2003) 655-660. 